\title{
A Planificação Municipal no Rio Grande do Sul
}

\author{
(A Codificação de Alegrete e Bagé)
}

\section{A. Delorenzo Neto}

$\mathrm{E}$ He que se serve a administraçáo municipal, inclui-se a da codificação, elemento necessário da planificação. (1) E uma técnica jurídica que se transforma em instrumento administrativo, e que representa o mais alto esfôrço do reajustamento procurando - pelo reexame de tôdas as condições, dos atos sujeitos à competência do município evitar tôda sorte de contradições, restabelecida uma base legal incontestável. Essa base legal uniformiza os critérios variáveis que informam a legislação esparsa, passando a garantir com maior eficácia as populações. Essa proteção dos interêsses do povo se opera pela substituição do direito incerto pelo direito certo, cujas normas se ajuntam, sob metodologia rigorosa, num texto único, ou seja, num código.

Tôda iniciativa que pretenda adotar a planificação como método administrativo, deve principiar pela reforma das leis locais. A primeira operação neste sentido é o planejamento da legislação, que se realiza através da codificação. Sem o apuro e o ordenamento dos textos que disciplinam a atividade local, não teremos serviços públicos organizados nem administração eficaz, e sim a rotina, o empirismo, o caos.

A codificação das leis municipais sob bases modernas, bem utilizados os recursos de comparação e hermenêutica, constitui uma necessidade inadiável. Facilitará aos administradores a prática da justiça através de uma aplicação mais perfeita da lei, constituindo, ainda, o meio mais adequado para a integração do direito municipal, no sentido de acolherem suas normas tudo quanto possa sugerir, no curso de suas transformações, a técnica e o progresso científico. Portanto, é imperioso que se promova maior eficácia à administração municipai, pela apuração e fixação dos textos, e precisão de processos, principalmente em matéria tributária. Os resultados que obtivemos em nossa experiência, levada a efeito em mais de trinta municípios, demonstram đe modo insofismável a importância e a utilidade prática da codificação. Esses resultados poderão ser examinados especialmente em relação aos municípios de Ourinhos e de Vitória, respectivamente nos Estados de São Paulo

(1) Cf. Delorenzo Neto, As Novas Tendências da Administração Mutnicipal, Pôrto Alegre, 1956. 
e do Espírito Santo, e revelam um crescimento de receita jamais atingido anteriormente, permitindo, em conseqüiência, o equacionamento dos respectivos problemas num quadro lógico, sob a garantia de uma vigorosa base jurídica financeira. (2)

De há muito, os Municípios de Alegrete (3) e Bagé, estavam a reclamar um trabalho de racionalização e conjuntura, à vista de sua estrutura urbana e rural, apresentando complexos problemas com profunda implicação regional.

De acôrdo com os últimos dados divulgados pelo I.B.G.E., constantes de monografia relativa a Alegrete, publicada em 1956 , a sua população é de 43.426 habitantes distribuídos numa área de 7.862 quilômetros quadrados. Com esta imensa e rica área rural, e concentração urbana apreciável, pois na cidade há atualmente 20.000 habitantes, não se apresenta situação financeira correlata, e sim muito aquém de suas possibilidades de desenvolvimento. E o que nos revela um pequeno balanço estatístico do crescimento da receita municipal, observado no qüinqüênio 1951-1955:

\begin{tabular}{|c|c|c|}
\hline & & $\$$ \\
\hline 95 & & $5.007 .000,00$ \\
\hline & & 6.159.000,00 \\
\hline & & $8.265 .000,00$ \\
\hline & & 7. $226.000,00$ \\
\hline & & $10.673 .000,00$ \\
\hline
\end{tabular}

Sendo assim, vê-se a precariedade Ja situação administrativa do ponto de vista dos recursos financeiros, considerando a necessidade de serviços públicos para uma comunhão humana de cêrca de $\mathbf{5 0 . 0 0 0}$ habitantes, com sério: problemas de desajustamento, valendo relembrar o bairro de Várzea Verde, com aproximadamente 2.000 habitantes. Neste bairro há 286 casas de madeira, quase tôdas em más condições, 49 casas de alvenaria e 11 construções mistas. Apresentam-se sem instalações sanitárias - 99; com fossa sêca, 228, e em más condições; com fossa asséptica, 4; e ligação de esgotos, 15. O lixo é sempre exposto. Não havendo abastecimento d'água regular, as bicás são insuficientes, e, em consequiência está sendo utilizada a água do rio (onde há dejetos do matadouro e esgotos).

Em reiação a Bagé, são os seguintes os dados, utilizada a monografia de 1955 , do I.B.G.E. A população é dè 66.172 habitantes distribuídos numa área de 7.054 quilômetros quadrados. O reparo feito em relação à situação financeira de Alegrete é válido com maior intensidade para Bagé - considerada a apreciável concentração urbana da cidade, com cêrca de 45.000 habitantes - observado o lento crescimento da receita no qüinqüênio 1949-1953:

\section{$\mathrm{Cr} \$$}

$10.274 .000,00$

$12.993 .000,00$

$12.085 .000,00$

$13.632 .000,00$

15. 357.000 .00

(2) Êsses dados comparativos podem ser examinados em nosso trabalho: $A$ Elaboração do Direito Municipal, São Paulo, 1955, pp. 14-16.

(3) Convém ier o notável reiatóric administrativo intitulado Alegrete e os seus Problemas, do General PEDRo PALMA, Prefeito de Alegrete em 1947, que tão bem situa os problemas do Município em face das exigências de planejamento. 
Em 1955, a receita atingiu o total de Cr\$ 20.949.899,50 e em 1956, Cr\$ 29.261.700,00, cujo aumento se verificou em virtude de devolução das quotas previstas no artigo 20 da Constituição Federal, ficando, porém, inalterado o crescimento das rendas originárias.

A capacidade contributiva dos habitantes de Bagé e Alegrete está longe de ser atingida, se refletimos sôbre o seu grau ótimo - indispensável a qualquer administração local - isto é Cr\$ $1.000,00$ per capita. De sorte que, a reforma empreendida para ambos os Municípios veio dotá-los de um novo sistema legal - já aprovado pelas Câmaras Municipais - em que se reexaminaram criteriosamente todos os textos vigentes, subordinando-se a sua metodologia à disposição expressa no Artigo 202, da Constituição Federal, que reza: "Os tributos terão caráter pessoal, sempre que isso fôr possível, e serão graduados conforme a capacidade econômica do contribuinte". De acôrcio com êste salutar princípio, organizamos os novos textos e tabelas dos Impostos Predial, Territorial Urbano, de Licença e de Indústrias e Profissões, respeitada sempre uma base proporcional e progressiva. As taxas foram inteiramente recompostas, extintas ou substituídas algumas, tendo sempre em vista c bem comum. Convém lembrar que as inovações mais importantes consistem na criação da "Contribuição para a Planificação Municipal" e da "União de Municípios". A "Contribuição para a Planificação" vem dotar as respectivas Prefeituras de um tributo específico, por meio do que enfrentarão tôdas as despesas dos estudos e pesquisas básicas relativas ao planejamento geral. A parte referente à "União de Municípios" representa inovação subs. tancial na técnica do planejamento de serviços comuns de caráter intermunicipal: Essa idéia, que agora adquire organicidade, foi por nós apresentada (4) ao VI Congresso Interámericano de Municípios, celebrado no Panamá, em agôsto de 1956, e conseguia, após debates memoráveis, apoio unânime, com expressa adesão à sua prática pelo eminente Alcalde Mayor de Bogotá, Don ANDré Rodriguez GOMez que, na sua ilustre Capital vem adotando c regime mais moderno de administração distrital descentralizada.

Quiséramos ver desenvolvida na plenitude da expansão econômica a imensa área da "campanha" gaúcha, tão rica nos seus recursos ainda mal utilizados, e tão altaneira pelas tradições. O sistema da "União de Municípios" poderá ser, certamente, o instrumento para a solução daqueles problemas que não podem de maneira precisa ser discriminados na esfera interna cia competência local, porque, pela sua própria natureza são indiscriminados e comuns. E o próprio senso gaúcho, um senso de hierarquia e de ordem já analisado com acuidade na obra de Oliveira Viana (5) - que exige uma reforma ampla, capaz de transformar a região privilegiada, a partir de uma ação administrativa permitindo investimentos de envergadura con aplicação social. Êsse rumo novo revelará, então, ao País, os valores da grancle área-local-comum da regiẽo pioneira do Rio Grande do Sul.

(4) Delorenzo Neto, o Problema da Expansão das Áreas Locais (Aspectos administrativos), Rio de Janeiro, 1957.

(5) "in" Populações Meridionais do Brasil, -2." Vol. (O Campeador Rio Grandense), Rio de Janeiro, 1952, pp. 279-287. 